\title{
Randomized comparison of two spacer devices in subjects with reversible airflow limitation
}

\author{
FRED W CLARKE BA BSc(HK) RCPT(P), LESLIE L MONTGOMERY BSc(HK) RCPT(P), \\ DAVID G STUBBING MB BS FRCPC \\ Department of Medicine, McMaster University, Hamilton, Ontario
}

FW Clarke, LI. Montgomery, DG Stubiring. Randomized comparison of two spacer devices in subjects with reversible airflow limitation. Can Respir J 1994;1(4):257-260.

OBJective: To asscss a new splacer device, the ACL, by comparing it with the Aerochimber in subjects with reversible airflow fimitation and atsessing the change in lung funclion atfer inhaled bronchodilator.

Design: A randemired single-blind cross-over trial was performed.

SETTING: Hospital-based pulmonary function laboralory.

Population Stunien: Thirty subjects with reversible arflow

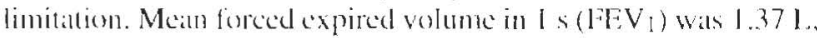
range $(9.8603 .3 \mathrm{~L}$. All subjects had previously shown at katst $15 \%$ reversibility after inhalied bronchoditator. All inhalled bronchodilators were witheld lor $6 \mathrm{~h}$. Subjects were studied on two separate days. Iour subjects were excluded from the final analysis because biscline IFI $\mathrm{V}_{\mathrm{i}}$ varied by greater than $10 \%$ between the wo study dilys. Maximum expiratory llow rates were used as the primary outcome mealsure. Change in heart ratle was assessed for adverse eflects.

INTERVENTIONS: The change in maximum expiallory flow ralle: was assessed 15 mins after two, three and four pufts of inhaled salbutamol delivered via one of the spaker devices. The use of spacer was randomired.

Results: Data from 20 subjects were analyzed. Baseline $\mathrm{FEV}$, was simitar on the lwo study dilys: $1.37 \pm 0.13 \mathrm{~L}$ (ACI:) and $1.38 \pm 0.14 \mathrm{I}$. (Aerochamber). The change in $\mathrm{Fl} \mathrm{V}_{\text {! }}$ was similar $(m$ both study days. The change in all the maximum expiratory tlow ralles wats similat with both spacer deviecs. liti $\mathrm{V}$ aller lour puth of salbutamol was $1.72 \pm 0.10 \mathrm{I}$. (ACE) and 1.7I $\pm 0.16 \mathrm{I}$ (Acro(liamber).

Covcussov: The bromehordiation acheved wats similar with both spacers. Beciuse the ACF is cheaper, it may offer cost savings to individuals or institutions.

Key Words: Asthma, Bronchodilators, Chromic olswertedive put-

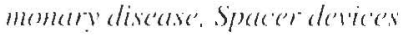

\section{Comparaison randomisée de deux dispositifs d'espacement chez des sujets présentant une limitation réversible du débit aérien}

OBJECTIF : Évaluer un nouveau disposilif d"espacement, l'ACL: en le comparant à l'Acrochambre ches des sujets présentant une limitation réversible du débit aérien, el estimer la variabilité dé ba fonction pumonate apres l'inhalation d'un bronchodilatateur. MoDîle: Essai randomisć croisé à simple insu.

CONTEXTE : Laboratnire de fonction puhmonaire d"un hôpital. Population Étudiée: Trente sujets présentaml une limitation réversible du débit aérien. Le volume expiratoire maximum sec ande (VLiMS) moyen était de 1,37 L, écart:0,8-3,3 L. Tous les sujcts avaient antérieurement fémontré une réversibilité d'alu moins $15 \%$ apres l'inhalation d'un bronchodilatateur. L'administration des bronchodilatitcurs par inhalation a été suspenduc pendant 6 heures. I es patticnts ont été ćtudiés au cours de deux jours distincts. Quatre stjects ont été exclus de l'analyse finale car leur VEMS de base avait varié de plus de $10 \%$ entre les deux jours d'étude. Les débits expiratoires de pointe (DEP) ont été retenus comme principale mesure objective. On a mesuré les variations du rylhme cardialyuc pour déceler les efléts indésirables.

INTERVENTIONS : I at variabilité des DEP a été évaluéc $15 \mathrm{~m} n$ apress la prise de deux, trois el yualre houffées de salbutamol en inhalattion auministrées à l'atide d'un des deux dispositits d'espacement. L utitisattion du disposilif d'espacement était ramelonisée. Résultats : Les domées recucillies sur 26 sujets unt ćté anit lysées. Le VEMS de base était identique pendant les deux jours

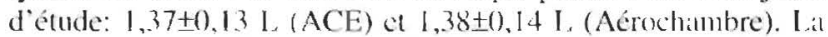
variabilité du VIEMS était similaire pendant les deux jours d’étude. Tous les DEP présentaient la méme variathilité qued que soil le dispositil d'espacement ulilisé. Le VEMS après quatre bouffées do

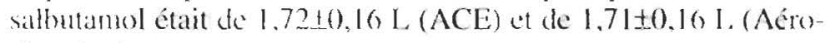
chambre).

Conclusion : Lat bronchodilatation shtenuc a l'aide des deux dispositifis d'espacement élat identicue. Moins coúleux. l'ACl' peut representer une source d'éparegne pour les individus el tes institutions.

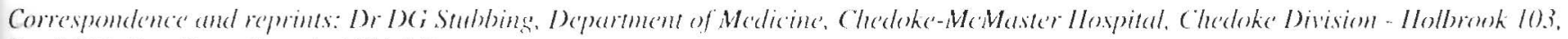
Box 200), Hemilton, Ontario I.SN .3\%. 
$\mathrm{T}$ HE METERIDD DOSI INHAIIER (MDI) IS THE DIVICLE MOSL commonly used to deliver drugs to the Iung in patients with obstructive lung discases. In many countries the MDI is used even in emergency situations as it has been shown that they are as effective as nebulizers but cost less (I-3). However. to obtain the optimum cflect from the inhaled drug the patient must master the technique needed to actuate the MDI and coordinate that action with inspiration. Several studies have shown that this is difficult for many patients (4-6) and spacer devices have been developed to simplify the technicute $(7-9)$.

In addition to improving delivery of the drug to the lung, spacer devices reduce oropharyngeal deposition of the inhaled medication, even in subjects who use the MDI in an optimal manner (10-12). Not only does this play a part in decreasing oropharyngeal adverse effects but it is particularly important now that it is recognized that inhaled steroids hatve the potential to produce systemic side effects (13-15). In order to minimise this potential for unwanted elfects it is standard practice to recommend that all patients taking high dose inhaled corticosteroids use a spacer device.

Most patients have to pay for their own spacer device and for many this cost is prohibitive. We have evaluated a new spacer, the ACE (Diemolding Healthcare Division, New York) which is approximately half the price of other spacers. We used a randomized, single-blind, cross-over design to compare the ACE with the Acrochamber (Trudell Medical) and assessed the change in lung function achicved after inhaled bronchodilator as the outcome measure.

\section{METHODS}

Thirty subjects with reversible arllow limitation were studicd. All had shown at least $15 \%$ improvement in mean forced expired volume in $1 \mathrm{~s}(\mathrm{FEV})$ in the three months before the study. All subjects were on inhaled corticosteroids and had been stable for at least one month before the study. Subjects were studied on two separate days in one week and at the same time of day.

() n each study day the subject withheld all inhaled bronchodilators for at least $6 \mathrm{~h}$. Baseline llow:volume curve was oblained (Sensormedics PFT Horizon System 5). The best
How:volume curve was selected by American Thoracic Society standards ( I6) from at least three attempts, and FiEV and maximum expiratory flow at $50 \%(\dot{V} 50)$ and $25 \%(\dot{V} 25)$ of vital capacity were obtained. Bascline heart rate was measured.

Two puts of inhaled bronchedilator (salbutamol) were then delivered using one of the spacer devices and 15 mins later measurements of flow and heart rate were repatcd.

After a third puff and a 15 min wail, and then a fourth puff and another 15 min wail, measurements were again made. On the second day the other spacer device was used. The order of use of spacer device was randomized.

The inhalation technique with aach spacer device was the same. Subjects were blindfolded and the technologist delivered the inhaled medication. The spacer kevice was placed in the subject's mouth and the subject was asked to seal the lips tightly. When the subject, breathing quictly, was at end expiratory lung volume the technologist atctuated the MDI and then asked the subject to inspire slowly to maximum inllattion, and hold their breath for 10 s. A second puff wats administered 30 s later in the same manner. Third and fourth puffs were delivered individually.

The inspiratory flow rate was controlled only by the whistling apparatus at the distal end of both devices. Alt the subjects hatd used the Aerochamber before the study and were familiar with the requirement to keep inspiratory flow rates low enough so als not to aclivate the whistle.

All subjects gave informed consent and the study was approved by the Hospital Research Advisory Committee.

Data from subjects were discarded il the baseline FEV I on the two study days differed by more than $10 \%$. Student paired $t$ test was used to analyze differences in FEV $1 . \dot{V} 50, \dot{V} 25$ and heart rate after two, three and four pulfs of inhated bronchodilator.

\section{RESULTS}

Eighteen men and 12 women (mean $\mid \pm S D]$ age $63 \pm[6$. range 20 to 79 years) were studicd. The mean FEV 1 at baseline was $1.38 \pm 0.66 \mathrm{~L}$ (range 0.8 10 3.3). Data from four subjects had to be discarded becausc there was greater than $10 \%$ difference in baseline $\mathrm{FEV}_{1}$ on the two study datys.

\section{TABLE 1}

Baseline lung function and changes after inhaled bronchodilator

\begin{tabular}{|c|c|c|c|c|c|c|}
\hline & \multicolumn{2}{|c|}{$\mathrm{FEV}_{1}$} & \multicolumn{2}{|c|}{$\dot{V} 50$} & \multicolumn{2}{|c|}{ V25 } \\
\hline & ACE & Aerochamber & ACE & Aerochamber & ACE & Aerochamber \\
\hline \multirow[t]{2}{*}{ Baseline } & $1.37 \pm 0.13$ & $1.38 \pm 0.14$ & $0.78 \pm 0.15$ & $0.85 \pm 0.16$ & $0.31 \pm 0.23$ & $0.32 \pm 0.28$ \\
\hline & \multicolumn{2}{|c|}{ Not significant } & \multicolumn{2}{|c|}{ Not significant } & \multicolumn{2}{|c|}{ Not significant } \\
\hline \multirow[t]{2}{*}{ Two puffs } & $1.62 \pm 0.16$ & $1.64 \pm 0,16$ & $1.03+0.22$ & $1.10 \pm 0.24$ & $0.38: 0.43$ & $0.40 \pm 0.5$ \\
\hline & \multicolumn{2}{|c|}{ Not significant } & \multicolumn{2}{|c|}{ Not significant } & \multicolumn{2}{|c|}{ Not significant } \\
\hline \multirow[t]{2}{*}{ Three puffs } & $1.68 \pm 0.16$ & $1.69 \pm 0.16$ & $1.10+0.27$ & $1.15 \pm 0.27$ & $0.39 \pm 0.48$ & $0.41 \pm 0.51$ \\
\hline & \multicolumn{2}{|c|}{ Not significant } & \multicolumn{2}{|c|}{ Not significant } & \multicolumn{2}{|c|}{ Not significant } \\
\hline \multirow[t]{2}{*}{ Four puffs } & $1.72+0.16$ & $1.71 \pm 0.16$ & $1.16 \pm 0.26$ & $1.16 \pm 0.26$ & $0.41 \pm 0.5$ & $0.42 \pm 0.56$ \\
\hline & \multicolumn{2}{|c|}{ Not significant } & \multicolumn{2}{|c|}{ Not significant } & \multicolumn{2}{|c|}{ Not significant } \\
\hline
\end{tabular}

Values are mean t standard error of the mean. FEV Forced expiratory volume in 1 s; $\vee 50$ Maximum expiratory flow at $50 \%$ of vital capacity; $V 25$ Maximum expiratory flow at $25 \%$ of vital capacity 


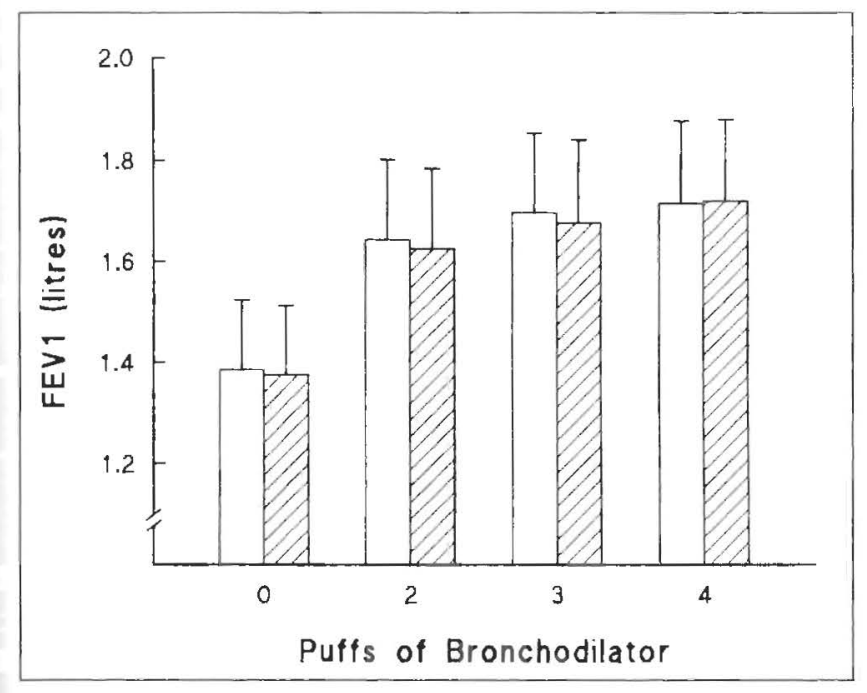

Figure 1) Forced expired wolume in $I s($ FEV $)$ before and after twe. three and four puffs of inhaled bronchodilator. Open bars - with Aerochamber: Hatched bars - with ACE: Values are means plus standard error

Excluding these data did not affeet the results of statistical analysis. Datu from 26 subjects were therefore used for the final analysis.

In all subjects on both study dilys there wals a significant increase in $\mathrm{FEV}_{\mathrm{I}}(\mathrm{P}<0.001)$ after inhaled bronchodilator. There was no difference in the increase in $\mathrm{FEV}_{1}$ on the two study days ( $P>0.25$, Table 1, Figure 1). There was also no difference in the change in $\mathrm{V} 50$ or $\mathrm{V} 25$ after inhaled bronchodilator with either spalcer device $(P>0) .25$. Table 1, Figure 2).

There was no change in heart rate even after four puffs of bronchodilator with either spacer device. With the ACE heart rate was $81.5 \pm 11.8$ beats/min at baseline and $79.2 \pm 10.7$ beats/min after bronchodilator. Using the Aerochamber the values were 83.() \pm 12.7 and $82.3 \pm 13.1$ beals/min, respectively.

\section{DISCUSSION}

This study hats shown that in patients with reversible airllow limitation inhaled bronchodilator delivered with it new spacer device, the ACE, results in increases in flow rates that are equivalent to those achieved when using the Acrochamber, probably the standard spacer device in general use in Canada. With cither spacer device, even after four puffs of inhaled bronchodilator, there was no increase in heart rate. This indicates that the ACE delivers adequate amounts of drug to the lung without a tendency to increase adverse effects.

We chose to compare the ACE with the Acrochamber in part becaluse the Acrochamber is the most commonly used device, but also beciuse the size of the spacers is similatr. The volume of the ACE is $170 \mathrm{~mL}$ while that of the Aerochatmber is $145 \mathrm{~mL}$. There is no clinical advantage 10 using larger spacers $(17,18)$.

The ACE and the Acrochamber are structurally different and yet shatre some similarities. They both have one-way inspirattory valves at the proximal end and whistling adaptors at the distal end. The ACE, however, has an entrainment hole

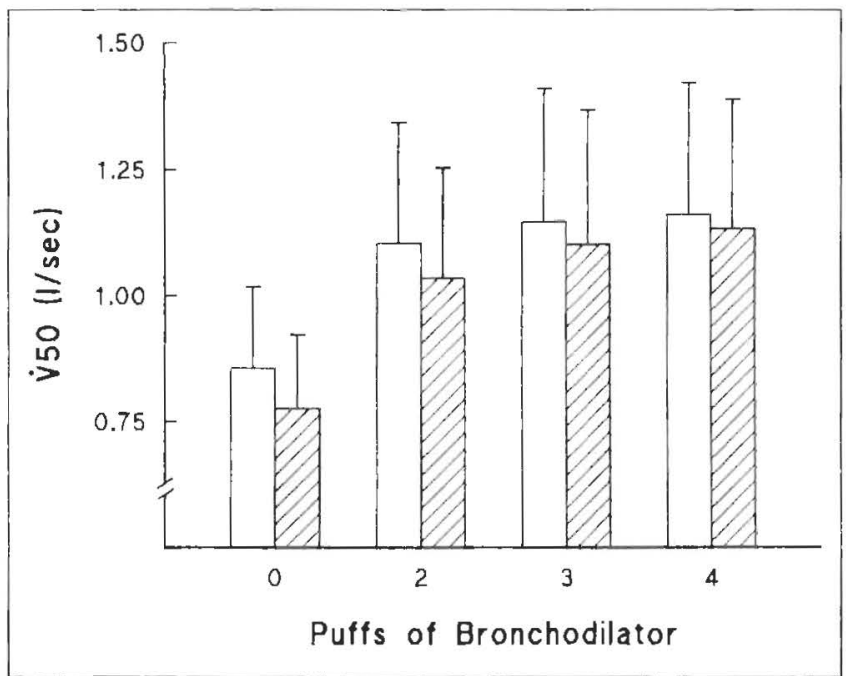

Figure 2) Maximum expiratory flow at $50 \%$ of vital ('apacity ( $\mathrm{V} 50$ ) before and after the, thre' and four puffs of inhaled bronchodilator. Open bars - with Acrochumber; Hatched bars - with ACE. Vulue's are' meins plus standard c'rort

proxinal to the valve. We did not find that this entraimment hole affected the bronchodilation that was achieved even at very low inspiratory flow rates in some of our subjects whose FEV I was less than $1 \mathrm{~L}$.

With the ACE the MDI canister itself is placed in the adaptive opening at the proximal end of the device in front of the inspiratory valve. With the Acrochamber not only the canister but the whole of the MDI is inserted into the rubber cap at the distal end of the device. The Acrochamber is therefore available for use with all MDIs whereas the ACE will only be applicable for canisters that fit the adaptive opening.

This study was single-blind with an cye mask preventing the subject from knowing which spacer device was used: the drug was delivered by the technologist. We used this method because we were testing the spacer device, not the ability of the subject to use an MDI and spacer.

As the study could not be double-bind we were coneerned about the possibility of technologist bias in determining which of the three flow volume curves oblained should be used for mealsurements. Bias was avorded by using American Thoracic Society standards to choose the best flow volume curve from which flow measurements were obtained (16).

We used changes in airway calibre alssessed by FEV I and $\dot{V} 50$ as the outcome measure because they reflect the potential clinical and symptomatic benefit to the patient with airflow limitation.

Although changes in lung function were similar whichever spacer device was used we cannol say that drug delivery to the lung was necessarily the same with both. However, rather than assess pulmonary deposition in this study, we chose to use the clinically relevant outcome nneasures of lung function changes.

The study sample size is larger than has been used in most previous assessments of spacer devices, but the possibility of 
at type II error exists. However, the differences in bronchodilation between the two spacer devices was negligible and even if a type II statistical emor were to exist, it is unlikely to be clinically relevant.

Spacer devices are now commonly recommended when an MDI is prescribed to improve drug delivery to the lung, reduce oropharyngeal side cflects, and minimize the total dose of drug delivered - an important lactor when high dose inhaled corticosteroids are used. They are particularly uselul in the clderly and in children.

The ACE, a new spacer device, in combination with salbutamol delivered from an MDI, resulted in bronchodilation

ACKNOWLEDGEMENTS: This study was funded in part by Diemolding Health Care Division, Canastota, New York. The authors thank Mary Hickcy lor her hilp in preparing the manuscript.

\section{REFERENCES}

I. Jenkins SC, Heaton RW, I ulton T.J, Moxham J. Comparison of domiciliary nebulized salbutamol and salbutamol from a metered-dose inhaler in stable chronic airflow limitation. Chest 1987;91:804-7.

2. Newhouse MT, Denlovich MB. Acrosol therapy: nebulizers vs metered dose inhaler. Chest 1987;91:740)-800.

3. Hodkter RV. Citl-utt LE, Leech JA. Metered dose inhaler with spacer is superior to wet nebulization for emergency room treatment of acute severe atshnua. Chest 1988;94:52S.

4. Oreheh J, Galyrard P. Grimatud CH, Charpin J. Pallent error in use of bronchodilator metered aerosols. BMJ 1476:1:70.

5. Epstein SW. Manning CPR, Ashley MJ, Corey PN. Survey of the clinical use of pressurized aerosol inhalers. Can Med Assoc J 1497): $128: 813-6$.

6. Shim C. Williams MH. The adequacy of inhalation of acrosol from cinnister nebulizers. Am J Med 1980;69:89) -4.

7. Godken DJ, Crompton GK. An objective assessment of the tube spacer in patients unahle to use a conventional pressurized aerosol cfficiently. Br J Dis Chest 1981;75:165-8.

8. Toogood JH, Baskerville J, Jemnings B, Lefcoe NM, Johansson S. Use of spacers to licilitatc inhaled corticosteroid treatment of asthma. Am Rev Respir Ijis 1984; 129:723-9.

9. Rachelefsky GS, Rohr $\triangle \mathrm{S}$, Wo J, et al. Use of a tube spacer to as good as that achicved with the present standard spacer. the Aerochamber. At present the cost ol the ACE is less than that of the Aerochamber and thus savings can acenc, whoul losis of benefit, to patients or to hospitals using spacer devices for clinical purposes. The use of either spacer device, however, does not negate the need to teach patients the optinat echnicue for inhalational therapy.

At present the appreximate cost on a pationt of the derochember. in a pharmacy in Ontartis, is $\$ 35$. (1) wherests the ACF costs

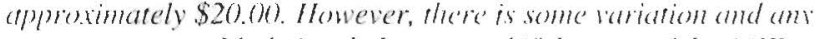
cost sentings would obriousty be nesated if the cost of the ACE nere increased or if the Acrochambre were redeced.

improve the efficacy of a metered-dose inhater in asthmattic children. Am J Dis Child 1986:1 40:1 19) 1 .3

10. Newman SP, Moren F. Pivia D), Little F, Clarke SW. Deposition of pressurized suspension akrosols inlailed through extension devices. Am Rev Respir Dis 1981:124:317-20.

11. Corr D, Dolovich M, McCormack D. Ruflin R. Obninski (i, Newhouse MT. Design and characteristics of a portable breath actuated, particle size selective medical icrosul inlater. J Aerosol Sci 1982:1 3:1-7.

12. Dolovich M, Ruflïn R, Corr D, Newhouse MT. Clinical evaluation of a simple demand inhalation MIDI acrosol delivery device. Chest 1983;84:36-41.

13. Brown PH, Blundell G, Greening AP, Crompton GK. Hypothalamus-pituitary-adrenal axis suppression in asthmlatics inhaling high dose corticosteroids. Respir Mc(l 1)9 1:85:5()1-10

14. Ali NJ, Capewell S, Ward MJ. Bone tumover during high dose inhaled corticosteroid treatment. Thorax 1901; $f(0: 160) 4$.

15. Mak VHF, Melchor R, Spiro S. Easy bruising als a sidc effect of inhaled corticosteroids. Eur Respir J 1992:5:1068-74.

16. American Thoracic Society. Standardization of spiometry 1987 update. Am Rev Respir Dis 1987: I 36:1285-98.

17. Crimi N, Palermo F, Cacopardo B, et al. Bronchudilator effect of Aerochamber and Inspirease in comparison with metered dose inhaler. Eur J Respir Dis 1987;7 I: 153-7.

18. Konig P, Gayer D, Kantak A, Kreutz C, Douglass B, Hordvik NL. A trial of metaproterenol by metered-dose inhaler and two spacers in preschool asthmatics. P'cdialt Puhmonol 1988:5:247-51. 


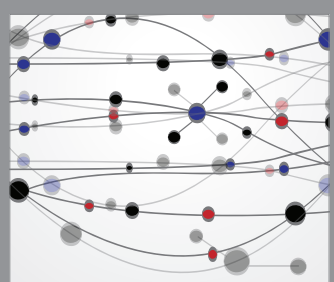

The Scientific World Journal
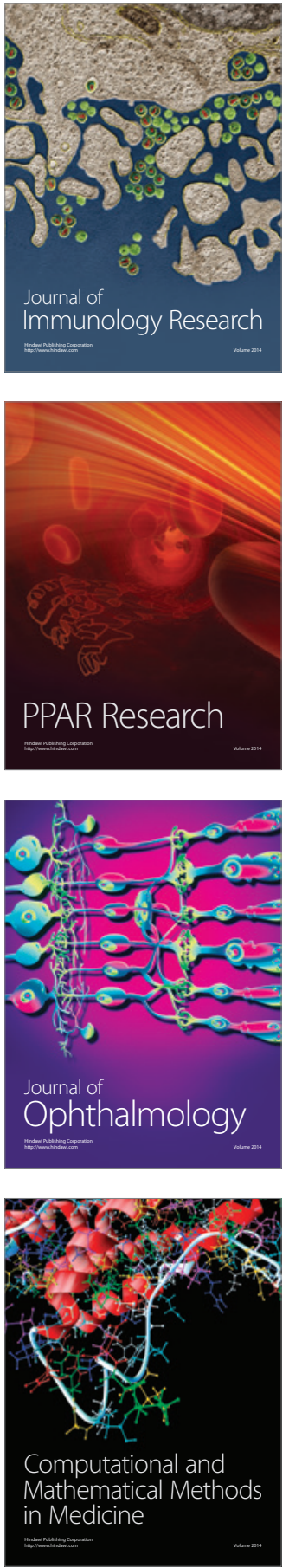

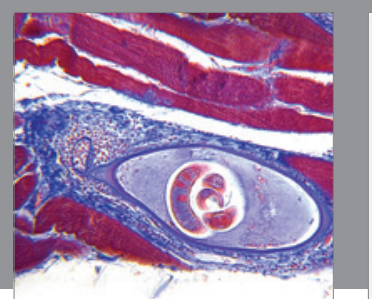

Gastroenterology Research and Practice

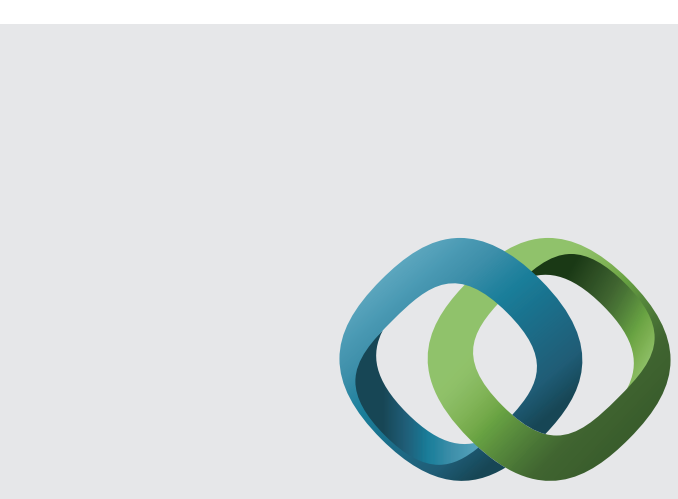

\section{Hindawi}

Submit your manuscripts at

http://www.hindawi.com
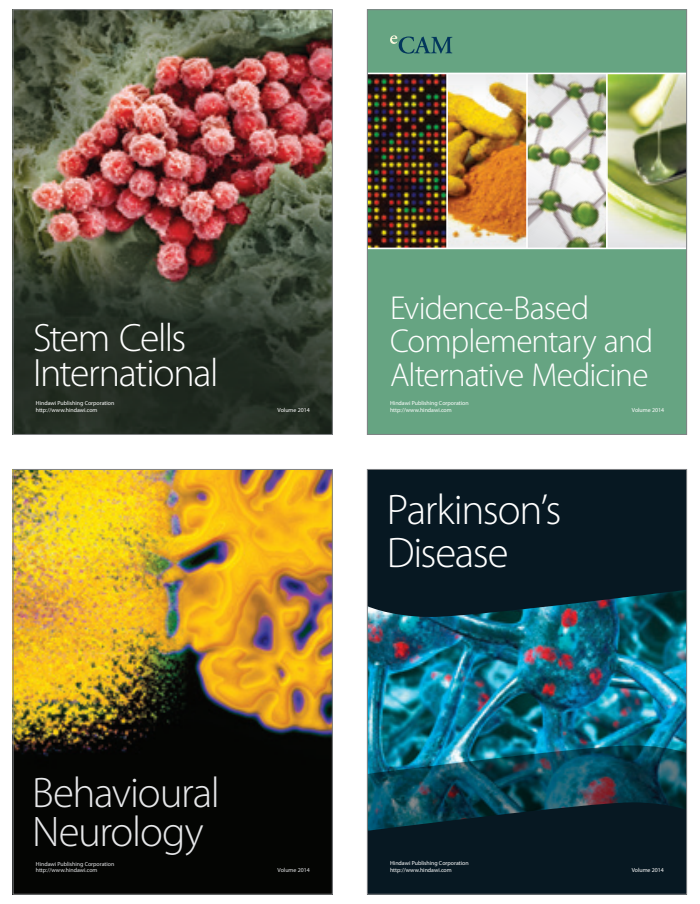
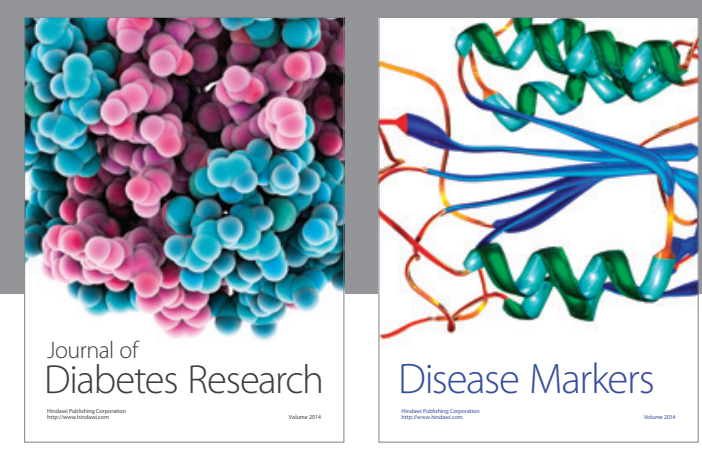

Disease Markers
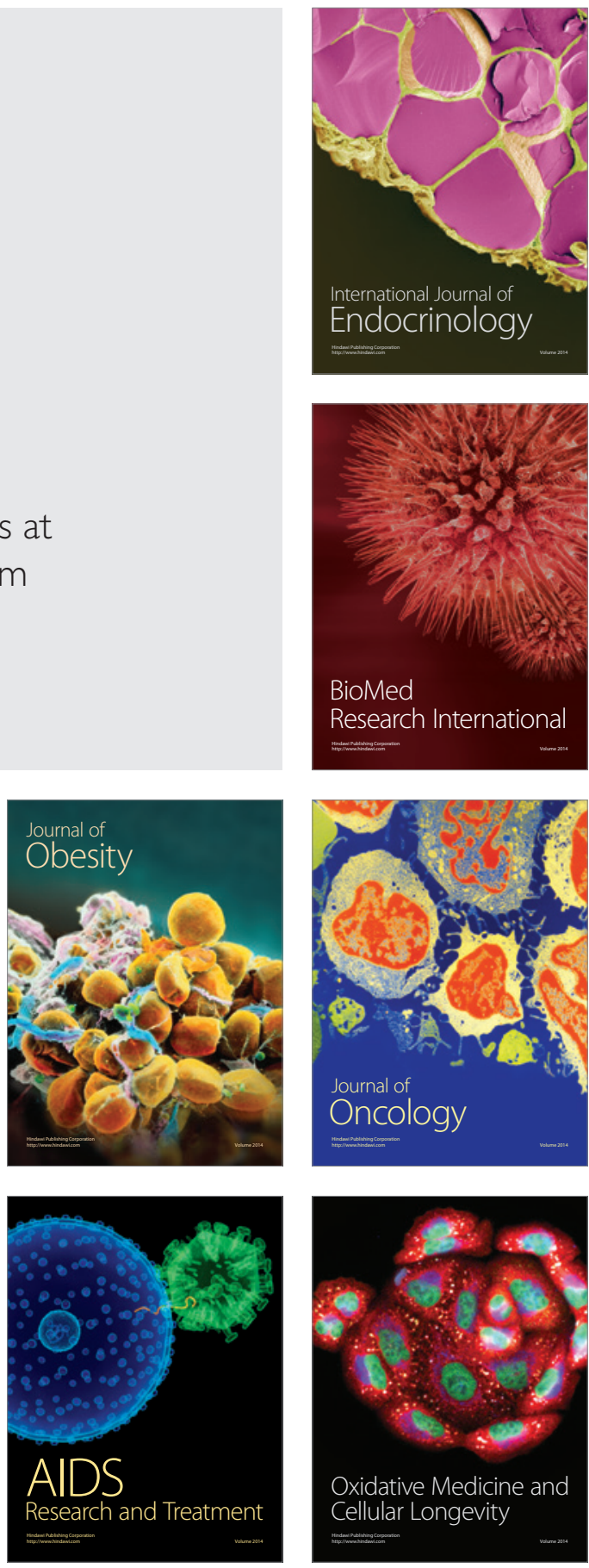